Coca's Gone 



\section{Coca's Gone}

\section{OF MIGHT AND RIGHT IN THE HUALLAGA POST-BOOM}

Richard Kernaghan 


\section{Stanford University Press}

Stanford, California

(C)2009 by the Board of Trustees of the Leland Stanford Junior University. All rights reserved.

No part of this book may be reproduced or transmitted in any form or by any means, electronic or mechanical, including photocopying and recording, or in any information storage or retrieval system without the prior written permission of Stanford University Press.

Printed in the United States of America on acid-free, archival-quality paper

Library of Congress Cataloging-in-Publication Data

Kernaghan, Richard.

Coca's gone : of might and right in the Huallaga post-boom / Richard Kernaghan. p. cm.

Includes bibliographical references and index.

ISBN 978-0-8047-5957-1 (cloth : alk. paper) -- ISBN 978-0-8047-5958-8 (pbk. : alk. paper)

1. Coca industry--Social aspects--Peru--Huallaga River Valley. 2. Insurgency--Peru--

Huallaga River Valley. 3. Political violence--Peru--Huallaga River Valley. 4. Huallaga

River Valley (Peru)--Economic conditions. 5. Cocaine industry--Peru--History. I. Title.

HD9019.C632K47 2009

$985^{\prime} \cdot 440643^{--\mathrm{dc} 22}$

$$
2009006807
$$

Typeset by Bruce Lundquist in 10/14 Minion 
for Angela 
